\title{
CORPORATE SECURITY DEPARTMENT OF PJSC «LUKOIL»AS MECHANISM OF ECONOMIC SECURITY MANAGEMENT
}

\section{Bikmurzina R. R. ${ }^{1}$, Melkonyan S. E. ${ }^{1}$, and Kolomiyets A. I. ${ }^{2}$}

${ }^{1}$ National Research Nuclear University MEPhl (Moscow Engineering Physics Institute), Kashirskoe shosse 31, Moscow, 115409, Russia

${ }^{2}$ Russian State University of Tourism and Service, PhD, Professor, associate professor RSUTS

\section{Abstract}

This article presents analysis of economic security structure on the example of LUKOIL PJSC, the internal Company documents were studied, stages of the managerial decisions making process concerning economic security issues were considered.

Keywords: economic security, corporate security, personal data, policy and strategy

Corresponding Author:

Bikmurzina R. R.

bikmu-regina@yandex.ru

Received: 11 December 2017

Accepted: 20 January 2018

Published: 13 February 2018

Publishing services provided by Knowledge

(c) Bikmurzina R. R. et al. This article is distributed under the terms of the Creative Commons Attribution License, which permits unrestricted use and redistribution provided that the original author and source are credited.

Selection and Peer-review under the responsibility of the FinTech and RegTech: Possibilities, Threats and Risks of Financial Technologies Conference Committee. of economic security, information protection

\section{Introduction}

To operate successfully, a thoroughly developed economic security policy and faultlessly implementable strategy of economic security of a business are needed.

Economic security policy of Lukoil PJSC sets the following tasks (http://www. lukoil.ru/static_6_5id_243_.html): to provide the solution of the objectives, on the up-to-date scientific and technical level, to train and improve the skills of employees within subdivisions of LUKOIL Group, in the field of industrial safety and occupational health, to bring the workplaces in the subdivisions of LUKOIL Group in accordance with the regulatory requirements.

\section{Material and Theoretical Bases of Research}

Strategy of economic security of Lukoil PJSC contains the following algorithm for detection of incompliances as well as development and implementation of corrective and preventative actions:

- Incompliance detection; 
- Development of corrective and preventative actions;

- Implementation of corrective and preventative actions;

- Transfer of information on the actions taken and their efficiency to the Company management to carry out appropriate analysis.

Since its foundation, Lukoil PJSC created Special Administration subdivision within the period of 1993-2002. Then, in 2002, Economic Security Management unit was founded based on Special Administration subdivision. Since 2004, all the issues concerning economic security structure of the Company have been studied by the Corporate Security Department.

Corporate Security Department includes Security Service based in Moscow. Personnel composition of the Security Service includes the Head of the Service and special working group consisting of 4-5 persons. Security Service of Lukoil PJSC successfully operates in five regions of the Russian Federation including Western Siberia, TimanPechora, the Transurals, the Volga Region, and the Kaliningrad Region. Official name of this subdivision is the Regional Administration of Security Service of Lukoil PJSC. This corporate unit maintains interconnection of work processes among the Service Head, three or four specialists, and the secretary (http://www. lukoil.ru/static_6_ 5id_29_.html).

Corporate Security Department structure is the responsibility of the Vice President of LUKOIL - A. A. Barkov.

In accordance with the concept, the President of the Company Vagit Alekperov carries out general management of all the activities on provision of Company security.

Objectives and tasks for creation of the Company security system include collection, processing and accumulation of the data, functions of information analysis and synthesis.

For all the time of Corporate Security Department operation significant changes have taken place twice. Firstly, in 2004 when the name of Economic Security Management unit was changed to Corporate Security Department. Secondly, in 2013 when the department management was changed.

Important advantage of the Company is availability of its own training institution on preparation and improvement of skills of Lukoil PJSC employees. At the same time, if it is necessary to train specialists on safety, occupational health or carry out occupational retraining of the employees, the Company signs agreements for provision of educational services with the training centers in Moscow, Moscow Region, etc. Staff 
appointments among the positions inside the Company are rather frequent that means employee loyalty and flexibility.

Economic security system analysis of the Company provides internal documents data studying. Internal document titled "Description of the Employee Workplace" was an object of the study. This document is presented as a scheme with description of a workplace location, equipping with furniture, ventilation facilities, temperature in the premise, cleaning schedule, list of tools, etc.

Regulation on Corporate Security Management is an important human resources document in Lukoil PJSC. Regional subdivisions also have Regulations on Corporate Security Management. General Regulation on Corporate Security Management is effective for all Company subdivisions. To organize activities of Administration, regulations of structural units included in Administration as well as position descriptions of the Administration employees are developed. Position descriptions of the Deputy Head of Administration, Heads of departments as well as the Administration employees, all the rules are clearly defined, obligations and responsibilities are approved by the Head of Administration. Thus, there is a wide range of regulations and requirements for each structural unit of the Company.

Personal data processing is also an important aspect in the Company (Regulation on Personal Data Processing of Lukoil PJSC). Personal data are processed based on the Regulation on Personal Data Processing and Federal Law FZ - 152 dated 27.07.2006 "On Personal Data". This Regulation includes information on general rules, sources for obtaining personal data processed, rights of personal data subjects, etc. In the contact details column there is information of a person, responsible for arrangement of the personal data processing is LUKOIL PJSC.

The next step will be a thorough review of "The Stages of the Managerial Decisions Making Process concerning Economic Security Issues". At the business meeting held once or more times a week the Head of Corporate Security Department S. P. Izotov, Head of Special Protection Systems and Information Security Administration A. Yu. Kuzminov as well as other leading specialists of the Company study and make decisions on current issues of the Company (including issues on personnel appointments, recruiting, industrial intelligence, environmental safety, information security, etc.). After that, the decisions on important issues are made by the Head of Corporate Security Service, Vice-President of the Company Anatoly Aleksandrovich Barkov.

In Lukoil PJSC there is its own corporate information system with an individual personal access for each employee. Its official name is Corporate System ibs.ru (http: // 
www. lukoil.ru/Company/Legal Inf ormation/PersonalDataProcessingPolicy). This system stores restricted information that is a commercial confidentiality (organizational structure of the departments, news, contacts, and local regulatory documents). In accordance with the Federal Law FZ-98 On Commercial Confidentiality, it is necessary to provide access for the Company employees to any information (production, technical, economic, organizational and the other) as well as information on the intellectual activity results in the scientific and technical field including data of the professional activity execution methods that are of actual or potential commercial value.

\section{Conclusion}

In case of using personal computer and other communication means the information in the Company is protected by the Special Protection Systems and Information Security Administration in cooperation with the Security Service of the Company.

Economic security issues are considered within the competence of the Corporate Security Department created in 2004. Personnel composition of the Corporate Security Department complies with the regulations on work organization concerning economic security issues. This structural unit is provided with all necessary local regulations settling and providing the department with systematic execution of procedure instructions.

\section{Acknowledgements}

This work was supported by Competitiveness Growth Program of the Federal Autonomous Educational Institution of Higher Education National Research Nuclear University MEPhl (Moscow Engineering Physics Institute).

\section{References}

[1] Federal Law FZ - 98 On Commercial Confidentiality // SPS Consultant Plus

[2] Federal Law FZ - 152 dated 27.07.2006 On Personal Data // SPS Consultant Plus

[3] Regulation on Personal Data Processing of Lukoil PJSC

[4] Regulation on Corporate Security Management of Lukoil PJSC

[5] Annual Report of Lukoil PJSC for the year 2015

[6] A. I. Kolomiyets Human Resources Management. NSEU HVE "IPI" - Moscow, 2013 
[7] http://www.lukoil.ru/Company/Legallnformation/PersonalDataProcessingPolicy

[8] http://www.lukoil.ru/static_6_5id_29_.html

[9] https://www.rosneft.ru/about/Glance/

[10] http://www.lukoil.ru/static_6_5id_243_.html

[11] https://www.rosneft.ru/Investors/dividends/

[12] http://ru.investing.com/equities/lukoil?cid=13689

[13] http://ru.investing.com/equities/rosneft?cid=13707 